\title{
Reverse passive haemagglutination test for the rapid identification of Neisseria gonorrhoeae and detection of penicillinase production
}

\author{
R. MUNRO AND R. MALLON \\ From the Department of Bacteriology, Institute of Clinical Pathology and Medical Research, \\ Wentworthville, Sydney, Australia
}

SUMMARY In a comparison of the reverse passive haemagglutination test (RPHA) with the direct immunofluorescent and rapid carbohydrate utilisation tests for the identification of Neisseria gonorrhoeae isolated from clinical specimens, 315 isolates of oxidase-positive Gram-negative diplococci were tested as pure 24-hour-old subcultures and samples from 108 similar organisms were taken directly from primary isolation plates. A similar test system was used to detect penicillinase production. Results showed agreement in $\mathbf{9 7 \cdot 8 \%}$ of organisms tested with the RPHA and conventional methods for identification of $N$. gonorrhoeae; similarly there was good agreement with conventional methods for detection of penicillinase production. The test was reliable and could be read within four hours; a result was therefore available on the same day the clinical specimen was received. The time and work involved in identifying $N$. gonorrhoeae using the RPHA was less than with conventional methods, but differentiation between $N$. gonorrhoeae and other Neisseria species from throat swabs proved difficult.

\section{Introduction}

Although a presumptive diagnosis of gonorrhoea is generally made at a venereal disease clinic on the basis of the findings in a Gram-stained smear, it is important to supplement and confirm this diagnosis in the laboratory (Jephcott et al., 1974). The laboratory must provide a rapid and definitive identification of Neisseria gonorrhoeae for this information to be of value to the clinician. At present we receive 10000 specimens per year for the isolation and identification of $N$. gonorrhoeae. The primary isolation medium used is modified New York City medium (Young, 1978a, b), and oxidase-positive, Gram-negative diplococci on these plates are further identified using direct immunofluorescence (Difco). Any organism giving a negative result is identified from a 24-hour-old pure subculture using a rapid carbohydrate utilisation test (Young et al., 1976). We find that approximately $83 \%$ of organisms can be

Address for reprints: Dr R. Munro, Department of Bacteriology, Institute of Clinical Pathology and Medical Research, PO Box 60, Wentworthville, Sydney, New South Wales 2145, Australia

Received for publication 8 April 1979 diagnosed by direct immunofluorescence from the primary isolation plate at $18-24$ hours but $17 \%$ of organisms require two tests for identification; this delays the results reaching the clinician by 24 hours and also adds to the cost of identifying the organism. The rapid carbohydrate utilisation test is most reliable when done with pure cultures; we have not consistently been able to obtain accurate results using organisms from primary isolation plates.

In an attempt to find a single test which would identify $N$. gonorrhoeae within 24 hours of the clinical specimen being taken, we have evaluated a reverse passive haemagglutination test (RPHA). This test detects a macroscopic agglutination reaction between a suspension of lysed $N$. gonorrhoeae and human group $\mathrm{O}$ red cells sensitised with rabbit antigonococcal antibodies. The results of this test were compared with those of the direct immunofluorescence and rapid carbohydrate utilisation tests. A similar system using human red cells sensitised with rabbit anti-penicillinase antibodies was evaluated for the detection of penicillinase production. Results were compared with the acidometric method of detecting penicillinase production described by Slack et al. (1977). 


\section{Material and methods}

Specimens were obtained from patients attending the Venereal Disease Clinic in Sydney. These were taken from the urethra and cervix in women and from the urethra, throat, and rectum in men. Swabs were inoculated on to modified New York City medium at the clinic, incubated at $36^{\circ} \mathrm{C}$ in candle jars, and transported to the laboratory the following day.

Initial evaluation of the RPHA was performed with 24-hour-old subcultures of suspected $N$. gonorrhoeae. At the end of that trial, a further 108 isolates were tested directly from the primary isolation plates. Organisms in the laboratory were incubated at $36^{\circ} \mathrm{C}$ in an atmosphere containing $10 \%$ $\mathrm{CO}_{2}$.

\section{REAGENTS}

The reagents used (Abbott Laboratories) were:

(1) Lyophilised anti- $N$. gonorrhoeae sensitised red cells (GONO-cells).

(2) Lyophilised anti-penicillinase sensitised red cells (PENI-cells). A blue dye was incorporated to facilitate reading of the test.

(3) Positive control (penicillinase-containing $N$. gonorrhoeae protoplasm). Preservative: thiomersal 1:10 000 .

(4) Negative control (Neisseria perflava protoplasm). Preservative: thiomersal 1:10 000.

(5) Specimen dilution buffer $(0.1 \mathrm{~m}$ phosphate buffer with protein and ion stabilisers). Preservative: $0 \cdot 1 \%$ sodium azide.

(6) Turbidity control (latex suspension adjusted to give an organism count of approximately $10^{6}$ organisms $/ \mathrm{ml}$.)

(7) A $25 \mu \mathrm{l}$ disposable dropper.

(8) Lysing solution (4 mol/1 sodium hydroxide).

All reagents were stored at $4^{\circ} \mathrm{C}$. Lyophilised red cells were reconstituted with distilled water and had a life of two weeks when stored at $4^{\circ} \mathrm{C}$.

\section{PREPARATION OF SPECIMENS}

Using a cotton-wool swab to facilitate mixing, colonies were removed from plates of modified New York City medium and an even suspension was made in $1 \mathrm{ml}$ of injection-quality distilled water to match the turbidity control. The suspension was then lysed with $5 \mu \mathrm{l}$ of $4 \mathrm{~mol} / \mathrm{l}$ sodium hydroxide using a precision micropipette. Only specimens which achieved a clarity comparable with a distilled-water blank in one minute were subsequently tested. (In fact, lysis of specimens was easily achieved, and no $N$. gonorrhoeae so far tested has failed to lyse.) The lysed specimens were then left for 15 minutes before the test was performed.

\section{PERFORMANCE OF ASSAYS}

A positive control, negative control, and specimen dilution buffer control were included in each test run. The microtitre trays used contained roundbottomed wells (Kayline Product TUS 96), although for performance of PENI-cell assays a more readable result was obtained with V-shaped wells.

Twenty-five microlitres of specimen dilution buffer was added to the required number of wells. Thereafter $5 \mu \mathrm{l}$ of lysed specimen, $5 \mu \mathrm{l}$ of positive control, and $5 \mu \mathrm{l}$ of negative control were added to the appropriate wells. When PENI-cell assays were also performed, all specimens were tested in duplicate. After being mixed, $25 \mu \mathrm{l}$ of GONO-cell and PENI-cell suspensions were added to each well containing controls and unknown specimens. The plates were shaken for two minutes using a Cooke microshaker. They were then left for a minimum of four hours on a non-vibrating surface at room temperature. Results were read with the aid of a test reading mirror. The positive GONO-cell control exhibited a dispersed red-brown settling pattern with an irregular periphery, and test specimens showing this pattern were read as positive. The positive PENIcell control showed a similar dispersed blue settling pattern, and test specimens showing this pattern were read as positive. A negative result consisted of a button of cells at the bottom of the well.

\section{REPRODUCIBILITY}

To ascertain the reproducibility of the test, one $N$. gonorrhoeae strain and one Neisseria meningitidis strain were selected and GONO-cell and PENI-cell assays performed on each isolate 25 times. These two organisms were then subcultured daily for eight days and GONO-cell and PENI-cell assays performed daily on the subcultures.

\section{SPECIFICITY}

Twenty-four-hour-old subcultures of six $N$. gonorrhoea and six $N$. meningitidis colonies were assayed with GONO-cells and PENI-cells. Six assays were also performed using GONO-cells with 24-hourold subcultures of Staphylococcus aureus, Proteus mirabilis, Pseudomonas aeruginosa, and a Moraxella strain.

\section{Results}

IDENTIFICATION OF N. GONORRHOEAE

The results obtained from clinical isolates of suspected gonococci are given in Tables 1 and 2 . Discrepancies between conventional methods of identification and RPHA are summarised in Table 3. Detection of penicillinase production is summarised in Table 4 and compared with conventional methods. 
Table 1 Results from 24-hour pure cultures of oxidase-positive, Gram-negative diplococci

\begin{tabular}{|c|c|c|c|c|c|c|c|}
\hline \multicolumn{2}{|c|}{ Patients investigated } & \multicolumn{3}{|c|}{$R P H A$ result } & \multicolumn{3}{|c|}{ Identified by direct IF and RCUT } \\
\hline Sex & Site & No. & + & - & N. gonorrhoeae & N. meningitidis & Other \\
\hline $\mathbf{M}$ & $\begin{array}{l}\text { Urethra } \\
\text { Rectum } \\
\text { Throat } \\
\text { Total }\end{array}$ & $\begin{array}{r}205 \\
53 \\
7 \\
265\end{array}$ & $\begin{array}{r}203 \\
51 \\
7\end{array}$ & $\begin{array}{l}2 \\
2\end{array}$ & $\begin{array}{r}205 \\
51 \\
4\end{array}$ & $\begin{array}{l}0 \\
1 \\
3\end{array}$ & $\begin{array}{l}0 \\
1 \\
0\end{array}$ \\
\hline $\mathbf{F}$ & $\begin{array}{l}\text { Urethra/cervix } \\
\text { Rectum } \\
\text { IUD } \\
\text { Total }\end{array}$ & $\begin{array}{r}48 \\
1 \\
1 \\
50\end{array}$ & $\begin{array}{r}48 \\
1 \\
1\end{array}$ & $\begin{array}{l}0 \\
0 \\
0\end{array}$ & $\begin{array}{r}48 \\
1 \\
1\end{array}$ & $\begin{array}{l}0 \\
0 \\
0\end{array}$ & $\begin{array}{l}0 \\
0 \\
0\end{array}$ \\
\hline Total $\mathrm{M}$ and $\mathrm{F}$ & All sites & 315 & 311 & 4 & 310 & 4 & 1 \\
\hline
\end{tabular}

+ Positive - negative

Direct IF $=$ Direct immunofluorescence (Difco)

RCUT = Rapid carbohydrate utilisation test

RPHA = Reverse passive haemagglutination

IUD = Intrauterine device

Table 2 Results of oxidase-positive, Gram-negative diplococci from primary isolation plates

\begin{tabular}{|c|c|c|c|c|c|c|c|}
\hline \multicolumn{2}{|c|}{ Patients investigated } & \multicolumn{3}{|c|}{$R P H A$ result } & \multicolumn{3}{|c|}{ Identified by direct IF and RCUT } \\
\hline Sex & Site & No. & + & - & N. gonorrhoeae & $N$. meningitidis & Other \\
\hline $\mathbf{M}$ & $\begin{array}{l}\text { Urethra } \\
\text { Rectum } \\
\text { Throat } \\
\text { Total }\end{array}$ & $\begin{array}{r}69 \\
17 \\
2 \\
88\end{array}$ & $\begin{array}{r}69 \\
17 \\
0\end{array}$ & $\begin{array}{l}0 \\
0\end{array}$ & $\begin{array}{r}69 \\
17 \\
0\end{array}$ & $\begin{array}{l}0 \\
0 \\
2\end{array}$ & $\begin{array}{l}0 \\
0 \\
0\end{array}$ \\
\hline $\mathbf{F}$ & $\begin{array}{l}\text { Urethra/cervix } \\
\text { Rectum } \\
\text { Total }\end{array}$ & $\begin{array}{r}20 \\
0 \\
20\end{array}$ & $\begin{array}{r}20 \\
0\end{array}$ & $\begin{array}{l}0 \\
0\end{array}$ & $\begin{array}{r}20 \\
0\end{array}$ & $\begin{array}{l}0 \\
0\end{array}$ & $\begin{array}{l}0 \\
0\end{array}$ \\
\hline Total $\mathrm{M}$ and $\mathrm{F}$ & All sites & 108 & 106 & 2 & 106 & 2 & 0 \\
\hline \multicolumn{8}{|c|}{$\begin{array}{l}+ \text { Positive }- \text { negative } \\
\text { Direct IF = Direct immunofluorescence (Difco) } \\
\text { RCUT = Rapid carbohydrate utilisation test } \\
\text { RPHA = Reverse passive haemagglutination }\end{array}$} \\
\hline \multirow[b]{2}{*}{ Sex of patient } & \multirow[b]{2}{*}{ Site } & & \multicolumn{3}{|c|}{$R P H A$ results } & & \\
\hline & & & No. of & ens & False-positive & False-negative & \\
\hline $\mathbf{M}$ & $\begin{array}{l}\text { Urethra } \\
\text { Rectum } \\
\text { Throat } \\
\text { Total }\end{array}$ & & $\begin{array}{r}274 \\
70 \\
9 \\
353\end{array}$ & & $\begin{array}{l}0 \\
2 \\
3 \\
5\end{array}$ & $\begin{array}{l}2 \\
2 \\
0 \\
4\end{array}$ & \\
\hline $\mathbf{F}$ & $\begin{array}{l}\text { Urethra } \\
\text { Rectum } \\
\text { IUD } \\
\text { Total }\end{array}$ & & $\begin{array}{r}68 \\
1 \\
1 \\
70\end{array}$ & & $\begin{array}{l}0 \\
0 \\
0 \\
0\end{array}$ & $\begin{array}{l}0 \\
0 \\
0 \\
0\end{array}$ & \\
\hline Total $\mathrm{M}$ and $\mathrm{F}$ & All sites & & 423 & & $5(1 \cdot 2 \%)$ & $4(1 \%)$ & \\
\hline
\end{tabular}

Table 4 Results of penicillinase production by $R P H A$ and conventional methods

\begin{tabular}{llll}
\hline & \multicolumn{2}{l}{ Test results } & \\
\cline { 2 - 4 } & + & - & Doubtful \\
\hline PENI-cell & 3 & 105 & 1 \\
Conventional methods & 3 & 106 & 0 \\
\hline
\end{tabular}

Reproducibility and specificity

On repeated subculture of one $N$. gonorrhoeae strain and one $N$. meningitidis strain the GONO-cell and PENI-cell assays gave consistent results. The GONOcell assay gave negative results with all organisms tested except $N$. gonorrhoeae.

There was no difference in the ability of RPHA to 
identify $N$. gonorrhoeae from 24-hour pure subcultures and from primary isolation plates. Overall the RPHA gave a false-positive rate of $1 \cdot 2 \%$ and a false-negative rate of $1 \%$ when compared with conventional methods. The false-positive results arose mainly from throat swabs containing $N$. meningitidis and, in one case, $N$. catarrhalis. It was noted during the study that several throat swabs contained both $N$. meningitidis and $N$. gonorrhoeae, and only careful scrutiny of isolation plates to identify both colonial types would prevent confusion in subsequent tests. The false-negative rate compared favourably with direct immunofluorescence suggesting that the rabbit antigonococcal antiserum used in the RPHA had a much broader spectrum of activity than that at present available in commercial immunofluorescent kits. The PENI-cell assay proved satisfactory for detecting penicillinase production.

\section{Discussion}

The RPHA has a number of advantages over the conventional methods we use at present for rapidly identifying $N$. gonorrhoeae and detecting penicillinase production. It enables a definitive diagnosis to be made the same day the clinical specimen is received (that is, after 18-24 hours incubation) in more cases than does direct immunofluorescence. The Venereal Disease Clinic thus has the result of culture by the time the patient is assessed at his follow-up visit. The main confusion with this test has occurred with throat swabs from which a high proportion of false-positive results was obtained. Since performing this trial, we have accumulated a further 13 throat swabs in which suspect $N$. gonorrhoeae was tested using the reverse passive haemagglutination test. All 13 swabs gave positive results but only four were confirmed as containing $N$. gonorrhoeae using conventional methods. Hence it is necessary to confirm the identity of Neisseria isolates from throat swabs with, for example, a rapid carbohydrate utilisation test.
The incubation time for this test is not critical and may be extended for up to 24 hours without affecting the result. Detection of penicillinase can be readily incorporated into the overall procedure. Since performing this trial, we have found a further eight organisms which produced penicillinase and all were satisfactorily identified by the RPHA test. These organisms had a minimum inhibitory concentration for penicillin of $>2 \mathrm{mg} / 1$. The test takes approximately the same time to set up as direct immunofluorescence, the results are easier to read, and the test is less open to misinterpretation. A clear-cut end result means that fewer indeterminate reactions need confirming with further tests.

A comparison with an acidometric method for detecting penicillinase production showed that they were equally successful.

In conclusion we have found that the RPHA for rapid identification of $N$. gonorrhoeae and detection of penicillinase production from primary isolation plates has advantages over the conventional methods used at present. However, it does not distinguish well between $N$. gonorrhoeae and other Neisseria, and other tests are preferable for identifying Neisseria organisms from throat swabs.

We wish to thank Mr J. Williams, Abbott Laboratories, for providing us with reagents to perform these tests, and Dr Ann Walker, Venereal Disease Clinic, Sydney, for clinical specimens.

\section{References}

Jephcott, A. E., Morton, R. S., and Turner, E. B. (1974). Use of transport-and-culture medium combined with immunofluorescence for the detection of gonorrhoea. Lancet, 2, 1311-14.

Slack, M. P. E., Wheldon, D. B., and Turk, D. C. (1977). A rapid test for beta-lactamase production by haemophilus influenzae. Lancet, 2, 906.

Young, H. (1978a). Cultural diagnosis of gonorrhoea with modified New York City (MNYC) medium. British Journal of Venereal Diseases. 54, 36-40.

Young, H. (1978b). Identification and penicillinase testing of Neisseria gonorrhoeae from primary isolation cultures of modified New York City medium. Journal of Clinical Microbiology, 7, 247-250.

Young, H., Paterson, I. C., and McDonald, D. R. (1976). Rapid carbohydrate utilization test for the identification of Neisseria gonorrhoeae. British Journal of Venereal Diseases, 52, 172-175. 